\title{
GROUNDS FOR LIMITING PROPERTY RIGHTS IN THE APPLICATION OF TEMPORARY SEIZURE OF PROPERTY IN CRIMINAL PROCEEDINGS
}

\author{
Tetiana Suprun ${ }^{1}$, Tetiana Yatsyk ${ }^{2}$ \\ University of the State Fiscal Service of Ukraine, Ukraine \\ Victoria Shkelebei ${ }^{3}$ \\ National University "Kyiv-Mohyla Academy" Kyiv, Ukraine
}

\begin{abstract}
The purpose of the paper is to investigate reasons for the restriction of property rights in the application of temporary seizure of property in criminal proceedings and to determine promising directions for further research on the issues. The issue of measures to ensure criminal proceedings and observance of human and civil rights and freedoms was investigated by a number of domestic scientists, but the degree of investigation of grounds for restricting property rights in the application of temporary seizure of property in criminal proceedings in the context of amendments made to the CPC of Ukraine in recent years remains insufficient. That is why the study of the grounds for limiting property rights in the application of temporary seizure of property in criminal proceedings is now of particular urgency. Methodology. Methodological basis of the research is a set of philosophical, general scientific, special scientific methods. The method of logical-semantic analysis is used to clarify the meaning of multi-valued concepts, the application of the method of system analysis allowed investigating the place of the institute of property rights in legal literature and legislation of Ukraine. The method of grouping and the system and structural approach are used for classifying the distribution, ascertaining the internal structure, and analysing the interconnections between elements of the concept of ownership and the category of property rights restriction. Results. The paper examines the factual and formal legal grounds for limiting the ownership of a suspect, accused, and other persons in the application of temporary seizure of property in a criminal proceeding. The conclusion is drawn on the need to clarify the factual grounds for the temporary seizure of property for cases where such a seizure is carried out by a person who has carried out legal detention in the manner prescribed by Articles 207, 208 of the CPC of Ukraine and is not an investigator, prosecutor, or other authorized official. Practical implications. Proposals regarding the resolution of individual legal conflicts in the current CPC of Ukraine are provided.
\end{abstract}

Key words: right of property, temporary seizure of property, restriction of individual rights, criminal proceedings.

JEL Classification: J00, K00, K11

\section{Introduction}

In modern conditions, the right of property is not only the basis of property independence of participants in public relations, which is a prerequisite for a market economy. At present, the inviolability of property rights has become, without exaggeration, one of the fundamentals of a modern democratic society and a rule of law. On this issue, one should agree with A.S. Nersesian, who observes: "Only citizens with property can claim to be the stable basis of the functioning of any society, and the illegal deprivation of property on the part of the state means its legal arbitrariness and inherent in the main authoritarian and totalitarian regimes" (Nersesian, 2015).

In these circumstances, mechanisms become important that allow ensuring a balance between private and public interests in criminal proceedings and creating preconditions for the persons who own the property to exercise their powers in relation to their property and, at the same time, to achieve the objectives of the

\footnotetext{
Corresponding author:

${ }^{1}$ Department of Criminal Law and Criminology, University of the State Fiscal Service of Ukraine.

E-mail: supruntanusha@gmail.com

${ }^{2}$ Department of Criminal Process and Criminalistics, University of the State Fiscal Service of Ukraine.

E-mail: zvezda171088@gmail.com

${ }^{3}$ Department of Criminal and Criminal-Procedure Law, National University "Kyiv-Mohyla Academy".

E-mail: shkelebei_vika@ukr.net
} 
criminal proceedings, which, as N.S. Morhun notes, in many cases, can only be carried out subject to the restriction or even deprivation of property rights during the investigation of criminal offenses (Morhun, 2015).

Therefore, the issue arises as to the grounds for limiting ownership in the application of temporary seizure of property in criminal proceedings.

The issue of measures to ensure criminal proceedings and respect for human and civil rights and freedoms was investigated by a number of domestic scholars such as Yu.P. Alenin, Yu.M. Hroshevyi, V.S. Zelenetskyi, O.P. Kuchynska, L.M. Loboiko, Yu.M. Miroshnychenko, O.R. Mykhailenko, N.S. Morhun, A.S. Nersesian, S.M. Smokov, and others.

However, the degree of investigation of grounds for restricting property rights in the application of temporary seizure of property in criminal proceedings in the context of changes made to the CPC of Ukraine in recent years is still insufficient.

Problem statement.

The main tasks solved by this article are as follows.

1. To investigate the grounds for limiting property rights in the application of temporary seizure of property in a criminal proceeding.

2. To identify promising directions for further research on the issues studied.

\section{Definition of the concept of property rights and the concept of inviolability of property rights}

Institute of property rights in the objective sense is complex (multidisciplinary), that is, that unites the rules of various branches of law, in particular, constitutional, civil, administrative, criminal. The said institution covers a set of rules that establish the general principles of property belonging to certain persons, and regulate and protect the belonging of material goods to specific individuals (Novoselova, 2001).

According to V.V. Aliamkin, the inviolability of property rights is a fundamental principle of guarantees of the protection of property rights and economic human rights, which is realized through the relevant material and procedural rules of the current legislation of Ukraine at the presumption level. This constitutional rule at the presumption level must be carried out unconditionally and provide both all the branches of law and the activities of state bodies, in particular, the judiciary. Any encroachment on property right is definitely unlawful if it is committed without the knowledge of the state and has no appropriate act of law enforcement (Aliamkin, 2011).

O.V. Dzera argues that the right to property is a statutory right, which establishes the absolute affiliation of property to a person (owner) and defines its rights and obligations with respect to this property (Dzera, 1996).
In the objective sense, the right of private property to citizens is a set of legal rules that establish and protect the citizens' ownership of property of the consumer and financial and productive purpose and provide owners with the right to own, use, and dispose of this property at their own discretion, to use it with any purpose, unless otherwise provided by law. Legal right of ownership is formed as a combination of the three most important powers - the right of ownership, the right to use, the right to dispose (Dzera, Kuznetsova, Pidopryhora, 2000).

The concept of inviolability of property rights as a basis for criminal proceedings is determined by N.S. Morhun as the original idea of the criminal process of a statutory nature, which consists in directing the content and form of criminal proceedings to protect the person from unlawful interference in its ability to own, use or dispose of its own property within the limits established by law at its own discretion (Morhun, 2015).

\section{The content of category of restriction on the right of ownership}

Regarding the content of the category of property rights restriction in the legal literature, there is currently no single position.

So, O.P. Kuchynska, T.I. Fulei, R.V. Barannik consider that restriction on the right of ownership is to remove certain powers from its content (Kuchynska, Fulei, Barannik, 2013). Instead, N.S. Morhun supports the position, by which the power to be restrained is not removed from the contents of the property right. The proprietor may exercise a limited subjective right only to the extent possible within the constraints. In the opinion of N.S. Morhun, restriction of property rights is a deterrent that prevents the owner from realizing his own private interest contrary to public interests. This restriction is imposed only on the basis of the law and does not remove the powers from the subjective right of ownership, but only blocks, in whole or in part, the possibility of its implementation (Morhun, 2015). O.V. Rozghon considers the restriction of the right of property as external influence on the subjective right of ownership of a particular person, embodied in the relevant legal relationship with his or her participation, involves compressing, reducing the ability of the owner to exercise his powers and consists in specific orders to the owner to take certain actions or refrain from certain actions (Rozghon, 2005).

Thus, the restriction on the right of ownership does not preclude the exercise of powers of the owner but allows it in the presence of certain conditions that must be observed. Restriction induces the owner to tolerate certain actions of third parties in the field of his legal domination or to refrain from certain actions (Aliamkin, 2011).

In view of the foregoing, for the purposes of this study, under the restriction of property rights in the application of temporary seizure of property in criminal proceedings, we propose to understand objectively existing 
circumstances of a temporary nature that by depriving a suspect, accused, and other persons of the possibility of exercising certain powers in relation to their property, limit the freedom to carry out actions with their property and consist of specific orders to the owner to take certain actions or refrain from certain actions.

In this case, the general features of the restriction on the right of property in the application of the temporary seizure of property will be as follows:

a) it is some oppression of the fullness of property rights;

b) necessarily formally defined, that is, enshrined in laws and regulations, moreover, solely at the level of law and the Fundamental Law;

c) is established given the public interests, namely, for the purpose of legal protection of rights and legitimate interests of other persons (Soloviov, 2011).

\section{Grounds of restriction on the right of ownership in criminal proceedings}

In relation to the issue of grounds of restriction on the right of ownership in criminal proceedings, it should be noted that, according to p. 2 of Article 223 of CPC of Ukraine (Holos Ukrainy, 2012), grounds for carrying out an investigative (search) activity are the availability of sufficient information indicating the possibility of reaching its goal.

In a criminal proceeding, grounds for carrying out an investigative (search) activity are conditions, upon which its conduct is possible, and these conditions are divided into factual and formal legal (Sheyfer, 1981). Using such a classification, in addition to theoretical needs, ensures a more faithful understanding and application of the law as related to conducting investigative (search) activity in practice, as well as the implementation of prosecutorial supervision, departmental and judicial control. As both factual and legal grounds for carrying out an investigative (search) activity can be subject to prosecutorial supervision, departmental and judicial control. Both legal and factual grounds can be subject to appeal, act as an independent subject of lawfulness and justification for conducting investigative (search) activity (Rudenko, 2015).

With the application of this approach in the study of the subject of this scientific work, the factual and formal legal grounds for limiting ownership in the application of temporary seizure of property in a criminal proceeding are subject to a priority analysis.

\section{Factual grounds of restriction on the right of ownership in the application of temporary seizure of property in criminal proceedings}

Factual grounds of restriction on the right of a person in the course of proceedings are a set of data sufficient to make a decision under the law as to the need to restrict certain rights of a person in such actions (Litvinova, 2017). Also quite common in the scientific literature is the definition of factual grounds for procedural action as sufficient data for the assumption that from the sources specified in the law information can be obtained that is the purpose of a certain procedural action (Shepitko, 2005). That is, the reasonableness of a certain procedural action is directly linked to the existence of the appropriate grounds for the conduct of such an action.

Legislation of Ukraine determines three grounds for temporary seizure of property: 1) legal detention of a person; 2) search; 3) examination. In turn, detention is divided into two groups: detention by any person ("ordinary citizen") and detention by an authorized person (Nersesian, 2015).

So, p. 2 of Article 207 of CPC of Ukraine (Holos Ukrainy, 2012) grants every person the right to conduct legal detention in the following cases: 1) committing or attempting to commit a criminal offense; 2) immediately after the commission of a criminal offense or the continuous prosecution of a person suspected of committing a crime. At the same time, according to p. 3 of Article 207 of the CPC of Ukraine (Holos Ukrainy, 2012), such a citizen has the duty to immediately deliver the detained person to an authorized official, or to immediately inform the authorized official of the detention and location of the person suspected of committing a criminal offense. In this case, the obligation to perform a temporary seizure of property is also assigned to this person.

Moreover, as A.S. Nersesian mentions, such a duty, in fact, gives the citizen the rights of an authorized official without giving him special training or real authoritative powers (Nersesian, 2015).

In the case when the person who carried out the detention notifies an authorized official of the fact of detention and is waiting for the departure of such an official at the place of commission of a criminal offense, this circumstance is not very significant. However, this situation is quite different in the case when a citizen who has stopped a pocket theft, or a street robbery or supermarket security that stopped a theft in the trading room, deliver the suspect to the investigation authorities or the prosecutor's office on their own. A.S. Nersesian quite rightly notes that in such cases, universal morality dictates to individuals the duty to return the stolen property to the legal owner, and the CPC of Ukraine - to carry out the temporary seizure of property. Obviously, failure to comply with the CPC rules, in this case, can at least be theoretically recognized as an offense, although it will be essential in the understanding of the criminalprocedural law - the issue is open and controversial (Nersesian, 2015).

The fact should also be noted that such a citizen, in accordance with p. 3 of Article 207 of the CPC of Ukraine (Holos Ukrainy, 2012) has a duty to immediately 
deliver the detained person to an authorized official, or immediatelyinform the authorized official of the detention and location of the person suspected of committing a criminal offense. In this case, the responsibility for fixing the temporal seizure of property is also assigned to a person, which imposes on him procedurally significant duties, which not only go beyond his competence and training but also can lead to the destruction or damage of traces of a criminal offense.

The issue of temporary seizure of property during a search or examination also deserves a particular attention. The procedural purpose of the search, in accordance with Article 234 of the CPC of Ukraine Holos Ukrainy, 2012), is the detection and recording of information about the circumstances of a criminal offense, the search for a criminal offense or property that was obtained as a result of its commission, as well as the location of wanted persons. The examination, in turn, is carried out with the aim of identifying and fixing information about the circumstances of the commission of a criminal offense.

Instead, the main purpose of the temporary seizure of property is:

- regarding the subject of a criminal offense - its return to the legal owner, and if this item is related to the illicit traffic - confiscation and destruction;

- in respect of funds or other property that was intended (used) to persuade a person to commit a criminal offense, to finance and/or provide material support for a criminal offense or reward for its commission, as well as for property (funds) obtained as a result of a criminal offense and/or revenues from them, as well as property in which they have been completely or partially converted - ensuring the interests of the state in the confiscation of property, as well as the victim (civil plaintiff) in the event of reimbursement of damage caused by a criminal offense.

So, according to A.S. Nersesian, only one group of things or documents included in the temporarily seized property can perform a unique evidentiary function found, manufactured, adapted or used as a means or tool for committing a criminal offense and (or) retained its traces (Nersesian, 2015).

It is also necessary to agree with the position of N.S. Morhun that the courts in practice often come to the conclusion that only the seized items and documents included in the list, on which the court was directly granted permission to find them, as well as the property arrested according to the rules of Article 98 of the CPC of Ukraine, can be recognized as evidence (Holos Ukrainy, 2012). At the same time, there is no provision in the current CPC for a temporarily seized property without the imposition of arrest by a court in accordance with rules of p. 5 of Article 171 of the CPC of Ukraine to be recognized as material evidence (Morhun, 2015).

Summing up the above, there is now a need to elaborate the factual grounds for the temporary seizure of property for cases where such seizure is carried out by a person who has carried out legal detention in the manner prescribed by Articles 207, 208 of the CPC of Ukraine (Holos Ukrainy, 2012) and is not an investigator, prosecutor, or another authorized official. We believe that for this category of persons, it is expedient to limit the list of things that may be temporarily withdrawn, taking into account the absence of special training of such persons. Then the relevant list should include: 1) things, documents, money, etc. used as means or tools for committing a criminal offense or who have kept its traces; 2) things, documents, money, etc., used to persuade a person to commit a criminal offense or reward for its commission; 3 ) things, documents, money, etc., which are the subject of a criminal offense, including those connected with their illicit circulation; 4) things, documents, money, etc., obtained as a result of a criminal offense.

\section{Formal legal grounds of restriction on the right of ownership in the application of temporary seizure of property in criminal proceedings}

In the general case, legal grounds are considered to be the set of conditions provided for in the criminalprocedural law that give an investigator the right to perform a certain investigative action (Kovalenko, 2008). A.P. Chernenko understands legal grounds as the relevant legal provisions foreseeing the circumstances with which these provisions come into force. These circumstances are the factual grounds, in the opinion of the said author (Chernenko, 2004). As legal grounds for the application of relevant enforcement measures, M.A. Pohoretskyi proposes to consider a number of conditions under the criminal procedural law that allow the authorized subject of criminal process to make a decision on their application (Pohoretskyi, 2007).

Regarding this issue, the opinion of O.M. Kalachova deserves attention; when classifying grounds of measures to ensure criminal proceedings, she uses terms "factual" and "formal" since factual grounds are always based on factual data, and formal - on a normal procedural form of giving a procedural status to a person as provided for in the legislation (Kalachova, 2008).

Under the legal ground of deprivation or restriction on the right of ownership in criminal proceedings, N.S. Morhun proposes to understand as a procedural document that gives an investigator, a prosecutor the right to perform a procedural action, during or after the results of which expropriation or restriction on the right of ownership is possible. For the most of procedural actions, which conduct is related to the expropriation or restriction on the right of ownership, according to N.S. Morhun, the decision of the investigating judge is such a legal ground (Morhun, 2015).

Given the above, for the purpose of this research, we propose to use the concept "formal legal grounds of 
restriction on the right of ownership in the application of temporary seizure of property in criminal proceedings" that we propose to understand as the relevant legal provisions foreseeing the circumstances with which these restrictions on the right of ownership in the application of temporary seizure of property in criminal proceedings come into force.

General conditions for conducting procedural actions and taking decisions aimed at deprivation or restriction on the right of ownership are:

a) the possibility of making a decision only by a court;

b) reasoning of this decision;

c) the adoption of a decision in accordance with the procedure provided for by the CPC of Ukraine.

The requirement for the adoption of a decision only by a court is that resolving the issue of restricting or depriving property right at the stage of pre-trial investigation can be carried out only by an investigating judge or a judge determined in accordance with Article 247 of the CPC of Ukraine (Holos Ukrainy, 2012).

The requirement to make a procedural act motivated obliges the court, justifying a court decision, to indicate the arguments that it used (took into account) for making the final conclusion. The statutory obligation to comply with the order of decision requires a court to decide on a case-by-case basis in strict conformity with the CPC rules governing the particular case of restriction or deprivation of property rights (Bandurka, Blazhivskyi, Burdol (etc.), 2012).

It should be noted that not all restrictions on property rights require a court decision in criminal proceedings. The given case is provided in accordance with p. 2 of Article 16 of the CPC of Ukraine (Holos Ukrainy, 2012), according to which the temporary seizure of property without a court decision is allowed. However, this restriction is possible only on the grounds and in the manner prescribed by the CPC of Ukraine.

Investigating the issue of formal legal grounds for restricting property rights in the application of temporary seizure of property in criminal proceedings should, first of all, be based on the fact that the general grounds for the temporary seizure of property are enshrined in Article 167 of the CPC of Ukraine (Holos Ukrainy, 2012).

According to the said article, temporary seizure of property is the actual deprivation of a suspect or persons owned by the property specified in paragraph 2 of this article, of the ability to own, use, and dispose of certain property before the decision on the issue of the seizure of property or its return. Temporarily seized may be property in the form of things, documents, money, etc., for which there are good reasons to believe that they are:

1) found, manufactured, adapted or used as a means or tool for committing a criminal offense and (or) retained its traces;

2) intended (used) to persuade a person to commit a criminal offense, to finance and/or provide financial support for a criminal offense or reward for its commission;

3) the subject of a criminal offense, including those associated with their illicit traffic;

4) obtained as a result of a criminal offense and/or revenues from them, as well as property in which they have been completely or partially converted.

This issue deserves a particular attention due to the fact that some scholars do not consider temporarily seized things, for which the investigating judge gave permission during the search (Myroshnychenko, 2013). Things and documents seized on the basis of the decision of the investigating judge, made on the basis of results of consideration of the petition of the investigator in accordance with Chapter 15 of the CPC of Ukraine are also not considered as such (Holos Ukrainy, 2012). Thus, the amendment to Part 2 of Article 168 of the CPC of Ukraine (Holos Ukrainy, 2012), paragraph 2 and 3, created a legal conflict, which consists in the fact that when a court decision specifies certain property to be seized (in this case, electronic information systems or their parts, mobile terminals of communication systems), then such property cannot be considered temporarily seized. In order to solve this collision, A.E. Rudenko proposes to amend paragraph 2 of Part 2 of Article 168 of the CPC of Ukraine (Holos Ukrainy, 2012) as to provide that the temporary seizure of electronic information systems or their parts, mobile terminals of communication systems for the study of physical properties that are important for criminal proceedings is forbidden It is proposed to seize such items only if they are included in the list, for which the explicit permission to search in the decision on the search permit is given (Rudenko, 2015).

Summarizing the above, formal legal grounds for the restriction on the right of ownership in the application of temporary seizure of property in criminal proceedings are the requirements of Article 167 of the CPC of Ukraine (Holos Ukrainy, 2012). In the case of the temporary seizure of electronic information systems or their parts, mobile terminals of communication systems for the study of physical properties that are important for criminal proceedings, such a reason is a court order, in which they are expressly indicated.

\section{Conclusions}

According to the results of the investigation of the factual and formal legal grounds for the restriction on the right of ownership in the application of temporary seizure of property in criminal proceedings, we can draw the following conclusions.

1. There is a need to clarify the factual grounds for the temporary seizure of property for cases where such seizure is carried out by a person who has carried out legal detention in the manner prescribed by Articles 207, 208 of the CPC of Ukraine (Holos Ukrainy, 2012) and 
is not an investigator, prosecutor, or other authorized official. For this category of persons, it is expedient to limit the list of things that may be temporarily seized, taking into account the absence of special training of such persons.

2. There is a need to resolve the legal conflict created after the addition of Part 2 of Article 168 of the CPC of
Ukraine (Holos Ukrainy, 2012) by paragraphs 2 and 3.

Taking into account the above, we consider the scientific search for solutions to the above-mentioned range of problems as one of the promising directions for further study of issues of restriction on the right of ownership of a suspect, accused, and other persons in criminal proceedings.

\section{References:}

Nersesian A. S. (2015) Zabezpechennia mainovykh prav hromadian i yurydychnykh osib pry zastosuvanni tymchasovoho vyluchennia maina u kryminalnomu provadzhenni [Provision of property rights of citizens and legal entities in the application of temporary seizure of property in criminal proceedings]. Sudova apeliatsiia, no. 2, pp. 50-56.

Morhun N. S. (2015) Zasada nedotorkanosti prava vlasnosti u dosudovomu kryminalnomu provadzhenni [The principle of inviolability of property rights in pre-trial criminal proceedings] ( $\mathrm{PhD}$ Thesis), Kyiv.

Novoselova L. A. (2001) Opredelenye obektov prava sobstvennosty [Definition of objects of ownership]. Hrazhdanyn y pravo, no. 2, pp. 21-27.

Aliamkin V.V. (2011) Dekilka mirkuvan shchodo zabezpechennia prava pryvatnoi vlasnosti [Several considerations regarding the provision of private property rights]. Pravo ta upravlinnia, no. 1, pp. 12-16.

Dzera O. V. (1996) Rozvytok prava vlasnosti hromadian v Ukraini [Development of property rights of citizens in Ukraine]. Kyiv: Venturi. (in Ukrainian)

Dzera O. V., Kuznetsova N. S., Pidopryhora O. A. (2000) Pravo vlasnosti v Ukraini [The right of property in Ukraine]. Kyiv: Yurinkom Inter. (in Ukrainian)

Kuchynska O. P., Fulei T. I., Barannik R. V. (2013) Pryntsypy kryminalnoho provadzhennia u svitli praktyky Yevropeiskoho sudu z prav liudyny [Principles of criminal proceedings in the light of the practice of the European Court of Human Rights]. Nizhyn: TOV "Vyd-vo "Aspekt-Polihraf”. (in Ukrainian)

Soloviov O. M. (2011) Obmezhennia prava vlasnosti: deiaki aspekty problem [Restriction on the right of ownership: some aspects of the problem]. Proceedings of the Aktualni problemy tsyvilnoho prava: materialy kruhloho stolu, prysviacheni pamiati profesora Chynhizkhana Nufatovycha Azimova (Ukraine, Kharkiv, December 23, 2010), Kharkiv: Pravo, pp. 107-109.

Holos Ukrainy (2012) Kryminalnyi protsesualnyi kodeks Ukrainy: Zakon Ukrainy vid 13 kvitnia 2012 r. [Criminal Procedural Code of Ukraine: Law of Ukraine on 13 April 2012]. Holos Ukrainy, no 90-91.

Sheyfer S. A. (1981) Sledstvennye deystviya. Sistema i protsessualnaya forma [Investigative actions. System and procedural form]. Moscow: Yurid. lit. (in Russian)

Rudenko A. E. (2015) Zakhody zabezpechennia kryminalnoho provadzhennia, shcho obmezhuiut mainovi prava pidozriuvanoho, obvynuvachenoho ta inshykh osib [Measures to ensure criminal proceedings restricting the property rights of the suspect, the accused, and other persons] (PhD Thesis), Kyiv.

Litvinova I. (2017) Pidstavy obmezhennia prava osoby na nedotorkannist zhytla u khodi obshuku [Grounds for restricting the right of a person to the inviolability of housing during the search]. Pidpryiemnytstvo, hospodarstvo $i$ pravo, no. 10, pp. 212-216.

Shepitko V. Yu. (2005) Kriminalistika [Criminalistics]. Kharkov: Odissey. (in Russian)

Rozghon O. V. (2005) Mezhi ta obmezhennia prava vlasnosti [Limits and restrictions on the right of property] (PhD Thesis), Kharkiv.

Kovalenko Ye. H. (2008) Kryminalnyi protses Ukrainy [The criminal process of Ukraine]. Kyiv : Yurinkom Inter. (in Ukrainian)

Chernenko A. P. (2004) Kryminalno-protsesualna rehlamentatsiia slidchykh dii [Criminal-procedural regulation of investigative actions] (PhD Thesis), Kharkiv.

Pohoretskyi M. A. (2007) Funktsionalne pryznachennia operatyvno-rozshukovoi diialnosti u kryminalnomu protsesi [The functional purpose of operative-search activity in the criminal process]. Kharkiv: Arsis LTD. (in Ukrainian)

Kalachova O. M. (2008) Vyznachennia slidchym protsesualnoho statusu osib, shcho berut uchast u dosudovomu provadzhenni [Definition by the investigator of the procedural status of persons participating in pre-trial proceedings] (PhD Thesis), Luhansk.

Bandurka O. M., Blazhivskyi Ye. M., Burdol Ye. P. (etc.) (2012) Kryminalnyi protsesualnyi kodeks Ukrainy. Naukovopraktychnyi komentar [Criminal Procedural Code of Ukraine. Scientific and practical commentary]. Kharkiv: Pravo. (in Úkrainian)

Myroshnychenko Yu. M. (2013) Problemni pytannia tymchasovoho vyluchennia y areshtu maina za novym kryminalno-protsesualnym zakonom [Problematic issues of temporary seizure and arrest of property under the new Criminal Procedure Law]. Porivnialno-analitychne pravo, no. 3, pp. 310-312. 